\title{
PENGARUH MINAT BELAJAR DAN KECERDASAN LOGIK MATEMATIK SISWA TERHADAP PRESTASI BELAJAR MATEMATIKA SISWA KELAS X SMK SE JAKARTA SELATAN
}

\author{
Andi Nur Rahman \\ Program Studi Matematika FMIPA UNPAM \\ andi.nur.rahman@gmail.com
} \begin{abstract}
regression analysis:

$$
\begin{aligned}
& \hat{Y}=9.556+0.222 X_{1}+0.464 X_{2} \\
& t_{\text {hitung }} \quad 8.687 \quad 25.324 \\
& \begin{array}{lll}
\text { sig. } & 0.000 \quad 0.000
\end{array} \\
& n=344 \\
& R=0.874 \\
& R^{2}=0.764 \\
& F_{\text {hitung }}=552.680 \\
& \text { sig. }=0.000
\end{aligned}
$$

Abstract

The purpose of this study was to determine the effect of learning interest on mathematics learning achievement. Knowing the influence of mathematical logical intelligence on mathematics learning achievement. Furthermore, to determine the effect of learning interest and mathematical logic of mathematics learning achievement. The research method used is the correlational survey method. Samples measuring 344 grade X students from 6 Vocational High Schools namely 18 Vocational High Schools, Averus Vocational Schools, 59 Vocational Schools, YPM Vocational Schools, Respati 3 Vocational Schools and Borobudur Vocational Schools, were selected using multi stage random sampling. Data collection is done by using questionnaires and test techniques. Data analysis using the method of correlation analysis and multiple regression. The statistical test used is the t test and $F$ test. The research was conducted on February 8, 2010 until November 30, 2010. The results of the study showed the influence of learning interest and mathematical logical intelligence together on mathematics learning achievement with multiple

From the equation shows that each increase in one unit of interest in learning will increase mathematics learning achievement by 0.222 units significantly. Likewise, every increase in one unit of mathematical logic intelligence will increase mathematics learning achievement by 0.464 units significantly. Furthermore, together, the variables of interest in learning and mathematical logical intelligence can determine the increase in mathematics learning achievement by $76.4 \%$ and very significant.

Keywords : Interest in Learning, Mathematical Logical Intelligence, Mathematics Learning Achievement

\begin{abstract}
Abstrak
Tujuan dari penelitian ini adalah untuk mengetahui pengaruh minat belajar terhadap prestasi belajar matematika. Mengetahui pengaruh kecerdasan logik matematik terhadap prestasi belajar matematika. Selanjutnya untuk mengetahui pengaruh minat belajar dan kecerdasan logik matematik terhadap prestasi belajar matematika. Metode penelitian yang digunakan adalah metode survey korelasional. Sampel berukuran 344 siswa kelas X dari 6 Sekolah Menengah Kejuruan yaitu SMKN 18, SMK Averus, SMKN 59, SMK YPM, SMK Respati 3 dan SMK Borobudur, dipilih dengan menggunakan multi stage random sampling. Pengumpulan data dilakukan dengan menggunakan teknik penyebaran angket dan teknik tes. Analisa data dengan menggunakan metode analisis korelasi dan regresi ganda. Uji statistik yang digunakan adalah uji t dan uji F. Penelitian ini dilaksanakan pada tanggal 8 Februari 2010 sampai dengan 30 November
\end{abstract}


2010. Hasil penelitian menunjukkan pengaruh minat belajar dan kecerdasan logik matematik secara bersama-sama terhadap prestasi belajar matematika dengan analisa regresi ganda :

$$
\begin{aligned}
& \hat{Y}=9.556+0.222 X_{1}+0.464 X_{2} \\
& t_{\text {hitung }} \quad 8.687 \quad 25.324 \\
& \begin{array}{lll}
\text { sig. } & 0.000 \quad 0.000
\end{array} \\
& n=344 \\
& R=0.874 \\
& R^{2}=0.764 \\
& F_{\text {hitung }}=552.680 \\
& \text { sig. }=0.000
\end{aligned}
$$

Dari persamaan tersebut menunjukkan setiap kenaikan satu unit minat belajar akan meningkatkan prestasi belajar matematika sebesar 0.222 unit secara signifikan. Begitu pula setiap kenaikan satu unit kecerdasan logik matematik akan meningkatkan prestasi belajar matematika sebesar 0.464 unit secara signifikan. Lebih lanjut secara bersama-sama menunjukkan bahwa variabel minat belajar dan kecerdasan logik matematik dapat menentukan peningkatan prestasi belajar matematika sebesar 76.4\% dan sangat signifikan.

Kata Kunci: Minat Belajar, Kecerdasan Logik Matematik, Prestasi Belajar Matematika

\section{PENDAHULUAN}

Pendidikan Nasional adalah pendidikan yang berdasarkan Pancasila dan Undang-Undang Dasar Negara Republik Indonesia Tahun 1945, yang berakar pada nilai-nilai agama, kebudayaan nasional Indonesia dan tanggap terhadap tuntutan perubahan zaman. Dalam UU 20/2003 tentang Sistem Pendidikan Nasional, Pasal 3, disebutkan "Pendidikan nasional berfungsi mengembangkan kemampuan dan membentuk watak serta peradaban bangsa yang bermartabat dalam rangka mencerdaskan kehidupan bangsa, bertujuan untuk berkembangnya potensi peserta didik agar menjadi manusia yang beriman dan bertakwa kepada Tuhan Yang Maha Esa, berakhlak mulia, sehat, berilmu, cakap, kreatif, mandiri, dan menjadi warga negara yang demokratis serta bertanggung jawab.

Dalam rangka menstandarkan pendidikan nasional di Indonesia maka ditetapkan Ujian Nasional. Ujian Nasional yang selanjutnya disebut UN adalah kegiatan pengukuran pencapaian kompetensi peserta didik pada beberapa mata pelajaran tertentu dalam kelompok mata pelajaran ilmu pengetahuan dan teknologi dalam rangka menilai pencapaian Standar Nasional Pendidikan. Materi yang di ujikan dalam ujian nasional untuk tingkat Sekolah Menengah Atas (SMA) atau Sekolah Menengah Kejuruan (SMK) yaitu Matematika, Bahasa Indonesia, dan Bahasa Inggris.

Matematika merupakan salah satu bidang studi yang sangat berguna baik dari segi teoritis maupun dari segi praktis. Pada kenyataannya semua bidang keilmuan maupun sektor kehidupan kita selalu dihadapkan kepada masalah-masalah yang memerlukan matematika sebagai pemecahannya. Contohnya, di mata pelajaran Biologi memerlukan teori peluang (probabilitas) untuk menghitung kemungkinan gen $\mathrm{X}$ dan $\mathrm{Y}$ yang akan mendominasi pada suatu keturunan, di mata pelajaran Akuntansi memerlukan operasi dasar matematika untuk membuat suatu neraca lajur, di mata pelajaran sejarah memerlukan cara membaca tahun suatu sejarah tertentu, dan kemampuan dasar matematika seorang siswa/i sangat dibutuhkan pada praktek kerja lapangan (Prakerin) untuk siswa/i SMK, serta kemampuan matematika siswa dari kelas X sampai dengan kelas XII akan diujikan melalui Ujian Nasional (UN) untuk mengukur kemampuan siswa tersebut, jika sudah mencapai standar nasional pendidikan maka dinyatakan nilai matematika siswa tersebut baik dan jika seluruh mata pelajaran yang di UN kan mendapat nilai di atas standar nasional pendidikan maka siswa tersebut dinyatakan lulus ujian. Akan tetapi menurut sebagian besar siswa/i, Matematika merupakan salah satu pelajaran yang paling 
"ditakuti", dan mereka juga kurang berminat untuk mengikuti pelajaran matematika apalagi jika materi yang diberikan oleh guru sangat sulit, sehingga sebagian besar siswa/i mendapatkan nilai yang kurang baik untuk setiap materi yang sangat sulit.

Faktor-faktor yang dapat mempengaruhi prestasi belajar matematika seorang siswa dapat dipengaruhi oleh beberapa faktor yaitu diantaranya adalah faktor eksternal dan faktor internal. Faktor eksternal adalah hal-hal yang berhubungan dengan prestasi belajar yang berasal dari luar diri siswa seperti guru, kurikulum, metode, media belajar, sarana belajar, lingkungan dan sebagainya. Sedangkan faktor internal yaitu hal-hal yang berhubungan dengan prestasi belajar yang berasal dari dalam diri siswa seperti kecerdasan, minat, bakat, sikap, motivasi, kebiasaan belajar, evaluasi diri dan sebagainya.

Menurut Howard Gardner yang dikutip oleh Bruce Campbell (2005:2), kecerdasan adalah "Kemampuan untuk menyelesaikan masalah yang terjadi dalam kehidupan manusia, kemampuan untuk menghasilkan persoalan-persoalan baru untuk diselesaikan, dan kemampuan untuk menciptakan sesuatu atau menawarkan jasa yang akan menimbulkan penghargaan dalam budaya seseorang”.

Setiap siswa memiliki kecerdasan yang berbeda-beda. Ada siswa yang dapat menciptakan seni visual yang indah. Ada siswa yang mahir di bidang olahraga, mereka mampu membuat gerakan-gerakan fisik yang mengagumkan dan penuh keberanian. Ada siswa yang mampu memainkan alat musik yang bagus sehingga bagi orang yang mendengarkan merasa tersentuh perasaannya. Ada yang merasa tergetar akan tantangan ketelitian matematis. Ada siswa yang suka menulis cerita-cerita dan puisi-puisi. Ada siswa yang mampu menjadi pemimpin yang alami dengan menawarkan model peran yang positif dan pembimbing yang dipercayai oleh teman sekelasnya. Ada juga yang memiliki wawasan personal yang menusuk tentang siapa mereka dan apa kegunaan mereka, sambil mengejar tujuan kehidupan yang utama. Contoh-contoh tersebut memperlihatkan para siswa memiliki kecerdasan dalam bentuk yang berbeda-beda. Tiap siswa itu unik dan semuanya secara individual, menawarkan kontribusi yang berharga bagi kebudayaan manusia.

Menurut Howard Gardner yang dikutip oleh Bruce Campbell (2005:2-3), manusia memiliki tujuh kecerdasan, diantaranya adalah : Pertama yaitu Linguistic Intelligence (Kecerdasan Linguistik) adalah kemampuan untuk berpikir dalam bentuk kata-kata dan menggunakan bahasa untuk mengekspresikan dan menghargai makna yang kompleks. Kedua yaitu Logical-Mathematical Intelligence (Kecerdasan Logik Matematik) merupakan kemampuan dalam menghitung, mengukur dan mempertimbangkan proposisi dan hipotesis, serta menyelesaikan operasi-operasi matematis. Ketiga yaitu Spatial Intelligence (Kecerdasan Spasial) membangkitkan kapasitas untuk berpikir dalam tiga cara dimensi, kecerdasan ini memungkinkan seseorang untuk merasakan bayangan eksternal dan internal, melukiskan kembali, merubah atau memodifikasi bayangan dan menghasilkan atau menguraikan informasi grafik. Keempat yaitu Bodily_Kinesthetic Intelligence (Kecerdasan Kinestetik Tubuh) memungkinkan seseorang untuk menggerakan objek dan keterampilan-keterampilan fisik yang halus. Kelima yaitu Musical Intelligence (Kecerdasan Musik) jelas terlihat pada seseorang yang memiliki sensitivitas pada pola titinada, melodi, ritme dan nada. Keenam yaitu Interpersonal Intelligence (Kecerdasan Interpersonal) merupakan kemampuan untuk memahami dan berinteraksi dengan orang lain secara efektif. Dan ketujuh yaitu Intrapersonal Intelligence (Kecerdasan Intrapersonal) merupakan kemampuan untuk membuat persepsi yang kuat tentang diri sendiri dan menggunakan pengetahuan semacam itu dalam merencanakan dan mengarahkan kehidupan seseorang.

Menurut Howard Gardner yang dikutip oleh Gorden Dryden dan Jeannette Vos (2000:121), Gardner berkata bahwa setiap orang memiliki beberapa tipe kecerdasan. Dua diantaranya yang sangat dihargai dalam pendidikan tradisional yaitu kecerdasan linguistik dan kecerdasan logik matematik. Kedua kecerdasan tersebut meskipun sangat dihargai dalam pendidikan tradisional saat ini, tetapi bukanlah tipe kecerdasan yang paling penting karena ada tipe-tipe kecerdasan yang lainnya yang saling berkaitan satu dengan yang lainnya. 
Kondisi belajar mengajar yang efektif adalah adanya minat dan perhatian siswa dalam belajar. Menurut Slameto (2003:180) minat adalah suatu rasa lebih suka dan rasa ketertarikan pada suatu hal atau aktifitas tanpa ada yang menyuruh. Keterlibatan siswa dalam belajar erat kaitannya dengan sifatsifat murid, baik yang bersifat kognitif seperti kecerdasan dan bakat maupun yang bersifat afektif seperti motivasi, rasa percaya diri, dan minatnya. Pada dasarnya setiap orang akan lebih senang melakukan sesuatu yang sesuai dengan minatnya (yang disukai) daripada melakukan sesuatu yang kurang disukai. Belajar dalam keadaan hari senang tentu saja akan lebih mudah daripada anak belajar dengan suasana hati yang terpaksa. Anak yang memiliki kecerdasan logik matematik, mereka senang belajar matematika, suka bertanya jika tidak tahu, rajin mengejakan pekerjaan rumah dan membeli buku penunjang, dll. Anak didik yang memiliki minat dan keingintahuan yang kurang untuk menekuni pelajaran matematika akan kesulitan dalam belajar matematika. Hal ini ditandai dengan masih rendahnya prestasi belajar yang dicapai.

Hal-hal yang berhubungan dengan prestasi belajar baik faktor eksternal maupun faktor internal memang sangat berpengaruh terhadap prestasi belajar matematika itu sendiri. Faktor internal merupakan hal-hal yang berasal dari dalam diri siswa yang dapat diukur, dimana faktor minat belajar dan kecerdasan logik matematiklah yang menurut penulis sangat berperan dalam keberhasilan belajar dari seorang siswa.

Berdasarkan penjelasan dari latar belakang diatas, maka penulis melakukan penelitian dengan judul "Pengaruh Minat Belajar dan Kecerdasan Logik Matematik Siswa Terhadap Prestasi Belajar Matematika Siswa kelas X SMK Se Jakarta Selatan”.

\section{METODE PENELITIAN}

Berdasarkan fokus permasalahan dan tujuan yang hendak dicapai, penelitian ini tergolong ke dalam metode survey karena melakukan pengukuran terhadap hal-hal yang nyata seperti mengukur minat belajar, kecerdasan numerik dan prestasi belajar matematika. Metode survey ini juga digunakan karena peneliti ingin memahami sesuatu fenomena (pengaruh minat belajar dan kecerdasan logik matematik siswa terhadap prestasi belajar matematika siswa kelas X SMK se-Jakarta Selatan) yang terjadi pada siswa kelas X SMK se-Jakarta Selatan.

Penelitian ini menggunakan teknik analisis korelasional yakni teknik yang dirancang untuk mengetahui seberapa besar pengaruh antara variabel bebas dengan variabel terikat. Dalam penelitian ini terdapat 2 variabel bebas yaitu :

$X_{1}$ :Minat belajar siswa kelas $\mathrm{X}$

$X_{2}$ :Kecerdasan logik matematik siswa kelas $\mathrm{X}$

dan satu variabel terikat yaitu

$Y$ : Prestasi belajar matematika siswa kelas $\mathrm{X}$

Model hubungan antara ketiga variabel penelitian ini dapat digambarkan dalam bentuk konstelasi permasalahan sebagai berikut:

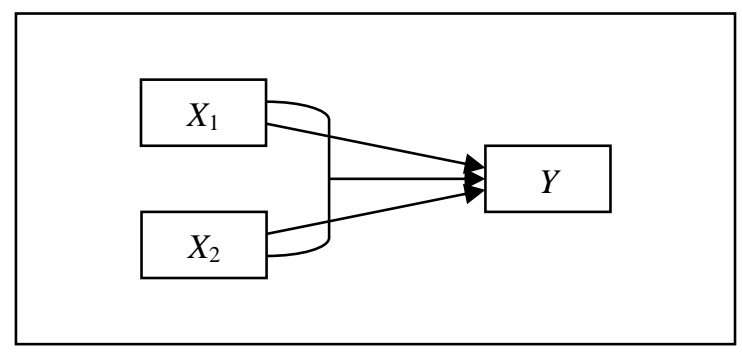

\section{Gambar 1 Konstelasi Permasalahan Penelitian}

Populasi dalam penelitian ini adalah seluruh siswa/siswi kelas X SMK se Jakarta Selatan tahun ajaran 2009/2010. Sekolah Menengah Kejuruan di Jakarta Selatan baik swasta maupun negeri ada sebanyak 103 sekolah, dengan rincian peringkat akreditasi sebagai berikut : SMK dengan peringkat 
akreditas A ada sebanyak 38 sekolah, SMK dengan peringkat akreditasi B ada sebanyak 57 sekolah, SMK dengan peringkat akreditasi $\mathrm{C}$ ada sebanyak 52 sekolah, SMK dengan peringkat akreditasi TT ada sebanyak 6 sekolah.

Teknik pengambilan sampel dalam penelitian ini menggunakan teknik multi stage random sampling. Sampel yang diambil ditetapkan sebanyak 344 siswa kelas X SMK. Adapun distribusi sampel dalam penelitian ini adalah sebagai berikut :

Tabel 1 Sampel Penelitian serta Peringkat Akreditasinya

\begin{tabular}{llcc}
\hline No & \multicolumn{1}{c}{ Nama Sekolah } & Peringkat Akreditasi & Jumlah Siswa/Responden \\
\hline 1. & SMK Averus & A & 60 siswa \\
2. & SMK Negeri 18 & A & 60 siswa \\
3. & SMK Negeri 59 & B & 60 siswa \\
4. & SMK YP Mulia & B & 60 siswa \\
5. & SMK Respati 3 & C & 60 siswa \\
6. & SMK Borobudur 2 & TT & 44 siswa \\
\hline \multicolumn{2}{c}{ Total Responden } & 344 siswa \\
\hline
\end{tabular}

Penentuan besarnya sampel ini didasarkan atas pertimbangan bahwa ukuran sampel tersebut telah mewakili karakteristik populasi dan telah memenuhi persyaratan analisis. Adapun sampel dalam uji coba instrumen penelitian dalam rangka untuk menguji validitas dan reliabilitas suatu instrumen penelitian sebelum dilakukan penelitian yang sebenarnya adalah siswa/i kelas X SMK Negeri 18 Jakarta sebanyak 60 orang. Perlu digaris bawahi bahwa sampel uji coba instrumen penelitian berbeda dengan sampel penelitian sebenarnya, meskipun kedua sampel diambil dari SMK Negeri 18 Jakarta, akan tetapi sampel untuk uji coba instrumen adalah siswa/i kelas X AK 1 dan 2 sedangkan sampel untuk penelitian sebenarnya adalah siswa/i kelas X AK 3 dan 4.

Metode pengumpulan data yang digunakan adalah metode survey dan teknik pengumpulan data dalam penelitian ini menggunakan instrumen dalam bentuk kuisioner dan tes. Teknik pengumpulan data untuk variabel minat belajar dengan menggunakan kuisioner minat belajar berupa angket minat siswa menggunakan skala likert dengan pilihan jawaban STS (Sangat Tidak Setuju), TS (Tidak Setuju), RR (Ragu-Ragu), S (Setuju), dan SS (Sangat Setuju) dimana untuk setiap pernyataan dengan kriteria positif (favourable) maka penentuan skornya adalah sebagai berikut : skor 1 untuk STS, skor 2 untuk TS, skor 3 untuk RR, skor 4 untuk S dan skor 5 untuk SS, sedangkan untuk setiap pernyataan dengan kriteria negatif (unfavourable) maka penentuan skornya adalah sebagai berikut : skor 5 untuk STS, skor 4 untuk TS, skor 3 untuk RR, skor 2 untuk S dan skor 1 untuk SS.

Teknik pengumpulan data untuk variabel kecerdasan logik matematik yaitu dengan menggunakan tes inteligensi berupa tes seri angka yang dikutip dari buku Soal-Soal Inteligensi Tes yang dibuat oleh Yul Iskandar. Teknik pengumpulan data untuk variabel prestasi belajar matematika dengan menggunakan tes akademik yang mengandung materi matematika kelas X SMK semester I diantaranya adalah operasi pada bilangan real, operasi pada bilangan berpangkat, operasi pada bilangan irasional, logaritma, persamaan dan pertidaksamaan linear, persamaan dan pertidaksamaan kuadrat. Jenis tes akademik tersebut terdiri dari 30 soal pilihan ganda. Data penelitian ini seperti data penelitian untuk variabel minat belajar, kecerdasan logik matematik dan prestasi belajar matematika diperoleh langsung dari sumber/responden sehingga disebut sebagai data primer.

Teknik analisis data yang digunakan dalam penelitian ini adalah teknik analisis korelasi regresi ganda. 


\section{HASIL DAN PEMBAHASAN}

\subsection{Deskripsi Data}

Data variabel minat belajar didapatkan dengan memberikan kuisioner sebanyak 30 pernyataan dengan pilihan jawaban Sangat Setuju (SS), Setuju (S), Ragu-Ragu (R), Tidak Setuju (TS) dan Sangat Tidak Setuju (STS), dan datanya dapat dilihat pada tabel 4.1 (terlampir). Data variabel kecerdasan logik matematik didapatkan dengan memberikan soal inteligensi berupa angka yang terdiri dari 20 soal pertanyaan, dan datanya dapat dilihat pada tabel 4.2 (terlampir). Sedangkan data variabel prestasi belajar matematika didapatkan dengan memberikan soal tes akademik matematika sebanyak 30 soal pilihan ganda.

Data minat belajar yang diperoleh dari hasil penelitian ke 6 sekolah menengah kejuruan didapatkan statistik deskriptif sebagai berikut :

$\begin{array}{ll}\text { Nilai minimum } & =70 \\ \text { Nilai maksimum } & =140 \\ \text { Nilai jangkauan } & =70 \\ \text { Nilai rata-rata } & =104,76 \\ \text { Nilai standar deviasi } & =18,931\end{array}$

Data kecerdasan logik matematik yang diperoleh dari hasil penelitian ke 6 sekolah menengah kejuruan didapatkan statistik deskriptif sebagai berikut :

Nilai minimum $\quad=5$

Nilai maksimum $\quad=95$

Nilai jangkauan $\quad=90$

Nilai rata-rata $\quad=45,7849$

Nilai standar deviasi $\quad=26,41550$

Data prestasi belajar matematika yang diperoleh dari hasil penelitian ke 6 sekolah menengah kejuruan didapatkan statistik deskriptif sebagai berikut :

$\begin{array}{ll}\text { Nilai minimum } & =23,33 \\ \text { Nilai maksimum } & =83,33 \\ \text { Nilai jangkauan } & =60 \\ \text { Nilai rata-rata } & =54,0598 \\ \text { Nilai standar deviasi } & =16,63144\end{array}$

\subsection{Pengujian Persyaratan Analisis}

Uji normalitas data prestasi belajar matematika dengan menggunakan kolmogorov - smirnov Z diketahui bahwa untuk variabel prestasi belajar matematika (variabel Y) diperoleh KolmogorovSmirnov $\mathrm{Z}=1.141$ dengan sig $=0.148>0.05$ sehingga $\mathrm{H}_{0}$ diterima maka dapat disimpulkan bahwa data prestasi belajar matematika berdistribusi normal. Uji Normalitas Galat Y (variabel prestasi belajar matematika) dengan menggunakan kolmogorov - smirnov $\mathrm{Z}$ diketahui bahwa data galat variabel prestasi belajar matematika (variabel $\mathrm{Y}$ ) diperoleh Kolmogorov-Smirnov $\mathrm{Z}=0.832$ dengan $\operatorname{sig}=0.493$ $>0.05$ sehingga $\mathrm{H}_{0}$ diterima maka dapat disimpulkan bahwa data galat prestasi belajar matematika berdistribusi normal. Uji Kolinearitas/Multikolinearitas, variabel bebas yang terdiri dari variabel minat belajar dan kecerdasan logik matematik pada analisis regresi disyaratkan tidak ada kolinearitas/multikolinearitas. Berdasarkan kriteria statistic tolerance yang menyatakan bahwa variabel bebas dinyatakan tidak ada kolinearitas/multikolinearitas apabila nilai Tolerance mendekati 1. Hal yang sama juga dikatakan bahwa kolinearitas/multikolinearitas tidak ada jika nilai VIF mendekati angka 1. nilai tolerance maupun VIF untuk masing-masing variabel bebas seperti variabel minat belajar dan variabel kecerdasan logik matematik mendekati angka 1. Jadi dapat disimpulkan bahwa kedua variabel minat belajar dan kecerdasan logik matematik tidak ada kolinearitas/multikolinearitas, sehingga analisis regresi dapat dipergunakan dalam penelitian ini. 


\subsection{Uji Linearitas}

Pengujian Kelinearan Regresi Minat Belajar terhadap Prestasi Belajar Matematika: $Y$ atas $X_{1}$ Hipotesis penelitian :

$\mathrm{H}_{0} \quad$ : Model regresi minat belajar terhadap prestasi belajar matematika berpola linear $\hat{Y}=1.869+0.498 X_{1}$

$\mathrm{H}_{1}$ : Model regresi minat belajar terhadap prestasi belajar matematika tidak berpola linear $\hat{Y} \neq 1.869+0.498 X_{1}$

Kriteria pengujian :

Jika nilai sig $<0.05$ maka $\mathrm{H}_{0}$ diterima dan $\mathrm{H}_{1}$ ditolak

Jika nilai sig > 0.05 maka $\mathrm{H}_{1}$ diterima dan $\mathrm{H}_{0}$ ditolak

Berdasarkan perhitungan hasil uji kelinearan regresi antara minat belajar terhadap prestasi belajar matematika dengan nilai $\mathrm{F}=166.285$ dan nilai sig. $=0.000<0.05$ sehingga $\mathrm{H}_{0}$ diterima maka dapat disimpulkan bahwa model regresi minat belajar terhadap prestasi belajar matematika berpola linear $\hat{Y}=1.869+0.498 X_{1}$.

Pengujian Kelinieran Regresi Kecerdasan Logik Matematik terhadap Prestasi Belajar Matematika: $Y$ atas $X_{2}$

Hipotesis penelitian :

$\mathrm{H}_{0} \quad$ : Model regresi kecerdasan logik matematik terhadap prestasi belajar matematika berpola linear $\hat{Y}=29.701+0.532 X_{2}$

$\mathrm{H}_{1} \quad$ : Model regresi kecerdasan logik matematik terhadap prestasi belajar matematika tidak berpola linear $\hat{Y} \neq 29.701+0.532 X_{2}$

Kriteria pengujian :

Jika nilai sig $<0.05$ maka $\mathrm{H}_{0}$ diterima dan $\mathrm{H}_{1}$ ditolak

Jika nilai sig > 0.05 maka $\mathrm{H}_{1}$ diterima dan $\mathrm{H}_{0}$ ditolak

Berdasarkan perhitungan hasil uji kelinearan regresi antara kecerdasan logik matematik terhadap prestasi belajar matematika dengan nilai $\mathrm{F}=850.673$ dan nilai sig. $=0.000<0.05$ sehingga $\mathrm{H}_{0}$ diterima maka dapat disimpulkan bahwa model regresi kecerdasan logik matematik terhadap prestasi belajar matematika berpola linear $\hat{Y}=29.701+0.532 X_{2}$.

\subsection{Pengujian Hipotesis Penelitian}

Pengujian Hipotesis I : terdapat pengaruh minat belajar $\left(X_{1}\right)$ terhadap prestasi belajar matematika $(Y)$. Dengan menggunakan SPSS 17 diperoleh sebagai berikut:

a. Koefisien Korelasi Sederhana $Y$ atas $X_{1}\left(R_{y 1}\right)$

Nilai koefisien korelasi sederhana $Y$ atas $X_{1}\left(R_{y 1}\right)$ sebesar 0.567

b. Koefisien Determinasi $Y$ atas $X_{1}\left(R_{y 1}^{2} \times 100 \%\right)$

Nilai koefisien determinasi $Y$ atas $X_{1}\left(R_{y 1}^{2} \times 100 \%\right)$ sebesar $32.1 \%$, hal ini menunjukkan besar kontribusi atau pengaruh minat belajar secara tunggal terhadap prestasi belajar matematika sebesar $32.1 \%$ dan $67.9 \%$ merupakan kontribusi dari variabel-variabel yang lainnya.

c. Uji $t$

Nilai $t_{\text {hitung }}=12.716$ dan sig. $=0.000<0.05$ maka $\mathrm{H}_{0}$ ditolak sehingga dapat disimpulkan bahwa terdapat hubungan positif minat belajar $\left(X_{1}\right)$ terhadap prestasi belajar matematika $(Y)$

d. Uji $F$ 
Nilai $F_{\text {hitung }}=161.699$ dan sig. $=0.000<0.05$ maka $\mathrm{H}_{0}$ ditolak sehingga dapat disimpulkan bahwa koefisien regresi minat belajar $\left(X_{1}\right)$ terhadap prestasi belajar matematika $(Y)$ berarti / signifikan.

e. Persamaan Regresi Sederhana. Persamaan regresi ganda minat belajar $\left(X_{1}\right)$ terhadap prestasi belajar matematika $(Y)$ adalah : $\hat{Y}=1.869+0.498 X_{1}$

Berdasarkan hasil pengujian diatas maka dapat disimpulkan bahwa terdapat pengaruh minat belajar $\left(X_{1}\right)$ terhadap prestasi belajar matematika $(Y)$. Pengujian Korelasi Parsial Minat Belajar $\left(X_{1}\right)$ terhadap Prestasi Belajar Matematika $(Y)$ pada saat Kecerdasan Logik Matematik $\left(X_{2}\right)$ dikendalikan.

Berdasarkan hasil pengujian yang diolah dengan menggunakan SPSS 17 diperoleh $r_{y 1,2}=0.808$ dengan sig. $=0.000<0.05$ maka $\mathrm{H}_{0}$ ditolak sehingga dapat disimpulkan bahwa terdapat hubungan parsial minat belajar $\left(X_{1}\right)$ terhadap prestasi belajar matematika $(Y)$ pada saat kecerdasan logik matematik $\left(X_{2}\right)$ dikendalikan

Pengujian Hipotesis II : terdapat pengaruh kecerdasan logik matematik $\left(X_{2}\right)$ terhadap prestasi belajar matematika $(Y)$. Dengan menggunakan SPSS 17 diperoleh sebagai berikut:

a. Koefisien Korelasi Sederhana $Y$ atas $X_{2}\left(R_{y 2}\right)$. Nilai koefisien korelasi sederhana $Y$ atas $X_{2}\left(R_{y 2}\right)$ sebesar 0.844

b. Koefisien Determinasi $Y$ atas $X_{2}\left(R_{y 2}^{2} \times 100 \%\right)$

Nilai koefisien determinasi $Y$ atas $X_{2}\left(R^{2}{ }_{y 2} \mathrm{x} 100 \%\right)$ sebesar $71.2 \%$, hal ini menunjukkan besar kontribusi atau pengaruh kecerdasan logik matematik secara tunggal terhadap prestasi belajar matematika sebesar $71.2 \%$ dan $28.8 \%$ merupakan kontribusi dari variabel-variabel yang lainnya.

c. Uji $t$

Nilai $t_{\text {hitung }}=29.087$ dan sig. $=0.000<0.05$ maka $\mathrm{H}_{0}$ ditolak sehingga dapat disimpulkan bahwa terdapat hubungan positif kecerdasan logik matematik $\left(X_{2}\right)$ terhadap prestasi belajar matematika $(Y)$

d. Uji $F$

Nilai $F_{\text {hitung }}=846.028$ dan sig. $=0.000<0.05$ maka $\mathrm{H}_{0}$ ditolak sehingga dapat disimpulkan bahwa koefisien regresi kecerdasan logik matematik $\left(X_{2}\right)$ terhadap prestasi belajar matematika $(Y)$ berarti / signifikan.

e. Persamaan Regresi Sederhana

Persamaan regresi ganda minat belajar $\left(X_{1}\right)$ terhadap prestasi belajar matematika $(Y)$ adalah: $\hat{Y}=29.701+0.532 X_{2}$

Berdasarkan hasil pengujian diatas maka dapat disimpulkan bahwa terdapat pengaruh kecerdasan logik matematik $\left(X_{2}\right)$ terhadap prestasi belajar matematika $(Y)$. Pengujian Korelasi Parsial Kecerdasan Logik Matematik $\left(X_{2}\right)$ terhadap Prestasi Belajar Matematika $(Y)$ pada saat Minat Belajar $\left(X_{1}\right)$ dikendalikan. Berdasarkan hasil pengujian yang diolah dengan menggunakan SPSS 17 diperoleh $r_{y 2,1}=$ 0.426 dengan sig. $=0.000<0.05$ maka $\mathrm{H}_{0}$ ditolak sehingga dapat disimpulkan bahwa terdapat hubungan parsial kecerdasan logik matematik $\left(X_{2}\right)$ terhadap prestasi belajar matematika $(Y)$ pada saat minat belajar $\left(X_{1}\right)$ dikendalikan

Pengujian Hipotesis III : terdapat pengaruh minat belajar $\left(X_{1}\right)$ dan kecerdasan logik matematik $\left(X_{2}\right)$ terhadap prestasi belajar matematika $(Y)$

Berdasarkan hasil pengujian yang diolah dengan menggunakan SPSS 17 dan ditunjukkan pada tabel 4.15 (terlampir), 4.16 (terlampir) dan 4.17 (terlampir) diperoleh sebagai berikut:

a. Koefisien Korelasi Sederhana $Y$ atas $X_{1}$ dan $X_{2}\left(\mathrm{R}_{\mathrm{y} 12}\right)$

Nilai koefisien korelasi sederhana $Y$ atas $X_{1}$ dan $X_{2}\left(\mathrm{R}_{\mathrm{y} 12}\right)$ sebesar 0.874

b. Koefisien Determinasi $Y$ atas $X_{1}$ dan $X_{2}\left(\mathrm{R}^{2}{ }_{\mathrm{y} 12} \times 100 \%\right)$ 
Nilai koefisien determinasi $Y$ atas $X_{1}$ dan $X_{2}\left(\mathrm{R}_{\mathrm{y} 12}^{2} \times 100 \%\right)$ sebesar $76.4 \%$, hal ini menunjukkan besar kontribusi atau pengaruh minat belajar dan kecerdasan logik matematik secara bersama-sama terhadap prestasi belajar matematika sebesar $76.4 \%$ dan $23.6 \%$ merupakan kontribusi dari variabel-variabel lain yang tidak termasuk dalam penelitian.

c. Uji $t$

Nilai $t_{\text {hitung }}$ minat belajar $=8.687$ dan sig. $=0.000<0.05$ dan nilai $t_{\text {hitung }}$ kecerdasan logik matematik $=25.324$ dan sig. $=0.000<0.05$ maka $\mathrm{H}_{0}$ ditolak sehingga dapat disimpulkan bahwa terdapat hubungan positif minat belajar $\left(X_{1}\right)$ dan kecerdasan logik matematik $\left(X_{2}\right)$ terhadap prestasi belajar matematika $(Y)$

d. Uji $F$

Nilai $F_{\text {hitung }}=552.680$ dan sig. $=0.000<0.05$ maka $\mathrm{H}_{0}$ ditolak sehingga dapat disimpulkan bahwa koefisien regresi ganda minat belajar $\left(X_{1}\right)$ dan kecerdasan logik matematik $\left(X_{2}\right)$ terhadap prestasi belajar matematika $(Y)$ berarti / signifikan.

e. Persamaan Regresi Ganda

Persamaan regresi ganda minat belajar $\left(X_{1}\right)$ dan kecerdasan logik matematik $\left(X_{2}\right)$ terhadap prestasi belajar matematika $(Y)$ adalah :

$$
\hat{Y}=9,556+0,222 X_{1}+0,464 X_{2}
$$

Berdasarkan hasil pengujian diatas maka dapat disimpulkan bahwa terdapat pengaruh minat belajar $\left(X_{1}\right)$ dan kecerdasan logik matematik $\left(X_{2}\right)$ terhadap prestasi belajar matematika $(Y)$.

\section{KESIMPULAN DAN SARAN}

Berdasarkan hasil pengumpulan, pengolahan dan analisa data penelitian yang berjudul "Pengaruh Minat Belajar dan Kecerdasan Logik Matematik Siswa Terhadap Prestasi Belajar Matematika Siswa Kelas X SMK se Jakarta Selatan" maka dapat disimpulkan sebagai berikut :

1) Pengaruh Minat Belajar Terhadap Prestasi Belajar Matematika Siswa Kelas X SMK se Jakarta Selatan.

Model regresi sederhana minat belajar $\left(X_{1}\right)$ terhadap prestasi belajar matematika $(Y)$ adalah $\hat{Y}=1.869+0.498 X_{1}$ artinya jika tidak ada nilai minat belajar maka prestasi belajar matematika siswa bernilai 1.869. Sedangkan setiap penambahan 1 unit nilai minat belajar akan meningkatkan nilai prestasi belajar matematika sebesar 0.498 pada konstanta 1.869 . Nilai $t_{\text {hitung }}=12.716$ dan sig. $=0.000<0.05$ maka $\mathrm{H}_{0}$ ditolak sehingga dapat disimpulkan bahwa terdapat hubungan positif minat belajar $\left(X_{1}\right)$ terhadap prestasi belajar matematika $(Y)$ siswa kelas x SMK se Jakarta Selatan Nilai $r_{y 1,2}$ $=0.808$ dengan sig. $=0.000<0.05$ maka $\mathrm{H}_{0}$ ditolak sehingga dapat disimpulkan bahwa terdapat hubungan parsial minat belajar $\left(X_{1}\right)$ terhadap prestasi belajar matematika $(Y)$ pada saat kecerdasan logik matematik $\left(X_{2}\right)$ dikendalikan Nilai $F_{\text {hitung }}=161.699$ dan sig. $=0.000<0.05$ maka $\mathrm{H}_{0}$ ditolak sehingga dapat disimpulkan bahwa koefisien regresi minat belajar $\left(X_{1}\right)$ terhadap prestasi belajar matematika $(Y)$ berarti / signifikan siswa kelas x SMK se Jakarta Selatan. Berdasarkan hasil analisa data di atas maka dapat disimpulkan bahwa terdapat pengaruh minat belajar $\left(X_{1}\right)$ terhadap prestasi belajar matematika $(Y)$ siswa kelas X SMK se Jakarta Selatan. Adapun besar kontribusi atau pengaruh minat belajar secara tunggal terhadap prestasi belajar matematika sebesar $32.1 \%$ dan 67.9\% merupakan kontribusi dari variabel-variabel yang lainnya.

2) Pengaruh Kecerdasan Logik Matematik Terhadap Prestasi Belajar Matematika Siswa Kelas X SMK se Jakarta Selatan.

Model regresi sederhana kecerdasan logik matematik $\left(X_{2}\right)$ terhadap prestasi belajar matematika $(Y)$

adalah $\hat{Y}=29.701+0.532 X_{2}$ artinya jika tidak ada nilai kecerdasan logik matematik maka prestasi belajar matematika siswa bernilai 29.701. Sedangkan setiap penambahan 1 unit nilai 
kecerdasan logik matematik akan meningkatkan nilai prestasi belajar matematika sebesar 0,532 pada konstanta 29.701. Diperoleh nilai $t_{\text {hitung }}=29.087$ dan sig. $=0.000<0.05$ maka $\mathrm{H}_{0}$ ditolak sehingga dapat disimpulkan bahwa terdapat hubungan positif kecerdasan logik matematik $\left(X_{2}\right)$ terhadap prestasi belajar matematika $(Y)$ Nilai $r_{y 2,1}=0.426$ dengan sig. $=0.000<0.05$ maka $\mathrm{H}_{0}$ ditolak sehingga dapat disimpulkan bahwa terdapat hubungan parsial kecerdasan logik matematik $\left(X_{2}\right)$ terhadap prestasi belajar matematika $(Y)$ pada saat minat belajar $\left(X_{1}\right)$ dikendalikan. Diperoleh nilai $F_{\text {hitung }}=846.028$ dan sig. $=0.000<0.05$ maka $\mathrm{H}_{0}$ ditolak sehingga dapat disimpulkan bahwa koefisien regresi kecerdasan logik matematik $\left(X_{2}\right)$ terhadap prestasi belajar matematika $(Y)$ berarti / signifikan. Berdasarkan hasil analisa data di atas maka dapat disimpulkan bahwa terdapat pengaruh kecerdasan logik matematik $\left(X_{2}\right)$ terhadap prestasi belajar matematika $(Y)$ siswa kelas X SMK se Jakarta Selatan. Adapun besar kontribusi atau pengaruh kecerdasan logik matematik secara tunggal terhadap prestasi belajar matematika sebesar $71.2 \%$ dan $28.8 \%$ merupakan kontribusi dari variabelvariabel yang lainnya.

3) Pengaruh Minat Belajar dan Kecerdasan Logik Matematik Terhadap Prestasi Belajar Matematika Siswa Kelas X SMK se Jakarta Selatan.

Model regresi ganda minat belajar $\left(X_{1}\right)$ dan kecerdasan logik matematik $\left(X_{2}\right)$ terhadap prestasi belajar matematika $(Y)$ adalah $\hat{Y}=9.556+0.222 X_{1}+0.464 X_{2}$ artinya jika tidak ada nilai minat belajar dan kecerdasan logik matematik maka prestasi belajar matematika siswa bernilai 9.556 . Sedangkan setiap penambahan 1 unit nilai minat belajar maka akan meningkatkan nilai prestasi belajar matematika sebesar 0.222 kali pada konstanta 9.556, dan setiap penambahan 1 unit nilai kecerdasan logik matematik maka akan meningkatkan nilai prestasi belajar matematika sebesar 0.464 kali pada konstanta 9.556. Berdasarkan hasil analisa data di atas maka dapat disimpulkan bahwa terdapat pengaruh minat belajar $\left(X_{1}\right)$ dan kecerdasan logik matematik $\left(X_{2}\right)$ terhadap prestasi belajar matematika $(Y)$ siswa kelas X SMK se Jakarta Selatan. Besar kontribusi atau pengaruh minat belajar dan kecerdasan logik matematik secara bersama-sama terhadap prestasi belajar matematika sebesar $76.4 \%$ dan $23.6 \%$ merupakan kontribusi dari variabel-variabel lain yang tidak termasuk dalam penelitian.

Berdasarkan kesimpulan dari hasil pengumpulan, pengolahan dan analisa data maka peneliti menyarankan sebagai berikut :

a. Bagi guru yang ingin meningkatkan prestasi belajar matematika siswa-siswinya hendaknya dapat menarik minat siswa dalam belajar matematika baik dengan berbagai cara agar siswa-siswinya mau berkonsentrasi, memahami dan melatih kemampuan terhadap materi yang diberikan.

b. Demi tercapainya tujuan pembelajaran matematika maka pihak sekolah diharapkan agar dapat mengadakan kegiatan yang berhubungan dengan peningkatan kecerdasan logik matematik siswa, karena salah satu indikator siswa-siswi dapat berhasil dalam pelajaran matematika adalah memiliki kecerdasan logik matematik yang baik.

c. Untuk lebih menyempurnakan penelitian ini maka variabel-variabel lain perlu ditambahkan sehingga dapat diketahui dan dipahami pengaruh-pengaruhnya terhadap prestasi belajar matematika.

\section{DAFTAR PUSTAKA}

Djaafar, Tengku Zahara. (2001). Kontribusi Strategi Pembelajaran Terhadap Hasil Belajar. Jakarta: Universitas Negeri Padang.

Ibrahim, Muslimin. (2000). Pembelajaran Kooperatif. Surabaya: UNESA Universitas Press.

Istarani. 2012. 58 Model Pembelajaran Inovatif. Medan : Media Persada 
Lie, Anita. (2002). Cooperative Learning (Mempraktikkan Pembelajaran Cooperative Learning di Ruang-Ruang Kelas). Jakarta: Grasindo.

Nazir, M. (2003). Metodologi Penelitian. Jakarta: Ghalia Indonesia.

Suherman, Erman. (2003). Strategi Pembelajaran Matematika Kontemporer. Bandung: JICA.

Sudjana. (2005). Metoda Statistika .Bandung: Tarsito. 